\title{
THE CHANGES IN THE BLOOD PRODUCED BY DEHYDRATION IN INFANCY *
}

BY

\author{
A. G. V. ALDRIDGE, M.A., M.D. \\ (From the Department of Diseases of Children in the University and the \\ Children's Hospital, Birmingham)
}

It is the purpose of this and a subsequent paper to record the result of a study of the effects of dehydration and the treatment of that condition carried out in a series of fifty-one infants in the years 1937-1938 during the tenure of a Caroline Harold Fellowship of the University of Birmingham. The objects of the investigation were: To determine the indications for the administration of fluid parenterally ; the best form of fluid to use ; the route by which it should be given ; the value of haematological and biochemical examination in forming a decision as to the most suitable fluid to use. In this paper the changes in the blood produced by dehydration are chiefly considered, and the subsequent paper is devoted to the treatment of that condition.

The majority of the children in this series were suffering from gastro-enteritis, but some were investigated before and after operation-chiefly for pyloric stenosis in infants and for hare lip and cleft palate in older children-and others who, on account of haemorrhage or for other reasons, were given blood transfusions. The investigations carried out on the blood comprised red cell counts, haemoglobin estimations, haematocrit readings and the estimation of plasma chloride and plasma protein concentrations. For these purposes very small amounts of heparinized blood (less than one-third of a cubic centimetre) were collected from the subject's heel or ear in tubes especially designed for the purpose ; it was thereby possible to carry out daily examination of the blood over long periods without causing an appreciable loss of blood to the patient.

\section{Methods}

Haematological. Red cells were counted in a Hawkesley's 'Improved Neubauer' chamber, and strict precautions were adopted to ensure that all counts were comparable. Haemoglobin was estimated by Haldane's colorimetric method ; if the solution was cloudy a drop of liquor ammonii fortis was added to disperse the turbidity. It was found that this addition did not affect the ultimate reading of the haemoglobin, but, as an additional precaution, if ammonia had been added it was used in every subsequent haemoglobin determination in that case. Haematocrit readings were calculated by centrifuging

- Part of a thesis submitted for the degree of M.D. of the University of Cambridge.

G 
specimens of heparinized whole blood at 8000 revolutions per second for half an hour, using specially designed micro-tubes made by Messrs. Baird and Tatlock. The results were recorded as percentages.

Biochemical. The blood was centrifuged within half an hour of collection and the plasma removed. If for any reason it was impossible to proceed immediately with the chemical investigations the plasma was placed in an icechest until this was possible. The changes in chloride and protein values after this treatment were always within the limits of experimental error. Chloride was estimated on 0.02 c.c. of plasma by Claudius's ultra-micro application of the open Carius method (Peters and van Slyke, 1931). Chloride values were calculated in terms of mgm. of $\mathrm{NaCl}$ per 100 c.c. of plasma, and in all references obtained from the literature the values are expressed in this way. Reasonable precautions were taken during the collection of specimens, but they were not taken under oil ; instead, it was decided that a standard method of collection was more practical. Provided that the plasma was removed at the earliest opportunity, and that the specimens were taken without undue shaking or exposure to air, the results were constant within 2 per cent. In a series of normal infants, however, since the specimens were collected at some distance from the laboratory, there was a greater interval between the collection of the blood and the estimation of chloride ; even so, the maximum range of the series was from 530 to $654 \mathrm{mgm}$. per cent. of $\mathrm{NaCl}$ (average 607), and only 19 (12 per cent.) of the 160 cases examined lay outside the usually accepted limits of 560 to $640 \mathrm{mgm}$. per cent. $\mathrm{NaCl}$. This suggests that the procedure gives a reasonably accurate picture of the chloride content of the blood, and can be used to follow its variations from day to day.

In order to reduce the volume of blood required, and to simplify the procedure, a measure of the daily variation of the plasma protein concentration was obtained by estimating the total nitrogen, and multiplying the figure by $6 \cdot 25$, the result being the amount of plasma protein in grammes per 100 c.c. No correction was made for non-protein nitrogen, although it was realized that this would often be greater than normal. For this estimation 0.02 c.c. of plasma was diluted up to 10 c.c. and 5 c.c. and this diluted fluid was used for the determination, employing Folin's modification of the Kjeldhal method, followed by direct Nesslerization with Koch and McMeekin's Nessler solution.

The chloride in urine and food was estimated by the open Carius method as applied by van Slyke and Sendroy (van Slyke, 1923) and Eisenman (1929).

In the tables that follow certain abbreviations have been used :

Hbn. Haemoglobin.

B.T. Blood transfusion.

D. and V. Diarrhoea and vomiting.

G-E. Gastro-enteritis.

P.S. Pyloric stenosis.

Imp. Improved.

P.U. Passed urine.

N.S. Normal saline.

5 per cent. g-s. 5 per cent. glucose solution in normal saline.

5 per cent. $g-\frac{1}{2} \mathrm{~s}$. 5 per cent. glucose solution in half normal saline $(0.45$ per cent.).

10 per cent. G. 10 per cent. aqueous solution of glucose.

m.e./litre. milli-equivalents per litre.

Ages are expressed as fractions of a year, e.g., 5/12 represents an age of 5 months. 


\section{CHARACTERISTICS OF DEHYDRATION}

Dehydration may be defined as the condition in which the water content of the body tissues is diminished, using the term 'body tissues' in its widest sense to include the skin, subcutaneous tissues, muscles, viscera and blood. It may result from deficient intake of water, excessive loss of fluid and salts, or a combination of these factors. The characteristic features of the condition may be considered under three headings, clinical, haematological and chemical. The chemical changes occurring in the blood of dehydrated children with gastro-enteritis and those with pyloric stenosis are not really comparable, since in gastro-enteritis the loss of fluid and base in the stools usually causes acidosis, whereas in pyloric stenosis the loss of chloride in the vomit may result in alkalosis. Consequently the chemical findings in the two conditions will be considered separately.

\section{Clinical features}

The infant's face, especially under the eyes, has a sunken and pinched appearance and the normal pigmentation under the lower lids is increased. The skin is dry and inelastic and tissue turgor is diminished, particularly in the subcutaneous tissues and muscles of the anterior abdominal wall. If the anterior fontanelle is still patent it is depressed, and the tongue and visible mucous membranes are dry. The pulse rate and respiration rates are increased ; there is a varying degree of pyrexia, oliguria, thirst and loss of weight. In the most marked type of dehydration, usually seen only in very severe gastro-enteritis, there may also be a peculiar ashen-grey colour of the skin, coldness and cyanosis of the extremities, a subnormal temperature and a restlessness which later gives way to drowsiness, stupor, or even coma. In such cases weakness is pronounced, and there may in consequence be difficulty in feeding and swallowing. Anuria may develop.

\section{Haematological features}

The viscosity of the blood is increased, and there is a diminished tendency to bleed from cut surfaces. The blood is more concentrated than normal and shows an increased red cell count, haemoglobin concentration and haematocrit readings. These features were demonstrated in the examination of forty-nine infants with varying degrees of dehydration. Of these, thirty-five suffered from gastro-enteritis and fourteen from congenital hypertrophic pyloric stenosis. The results obtained in the investigation of these patients are set out in tables 1 , 2,3 . In table 1 are shown the results of examination of the blood carried out in thirty-one patients before parenteral administration of fluid, and table 2 summarizes the findings in the remaining eighteen cases, which, because of the seriousness of their condition, had all been treated with parenteral fluid before investigation of the blood. Many infants become more dehydrated during the course of their illness, and table 3 shows the most extreme changes which occurred in such children. 
TABLE 1

THE CHANGES IN THE BLOOD IN DEHYDRATION

\begin{tabular}{|c|c|c|c|c|c|c|}
\hline CASE & . & AGE & $\begin{array}{l}\text { CLINICAL } \\
\text { CONDITION }\end{array}$ & $\begin{array}{l}\text { RED CELLS } \\
\text { (MILLIONS } \\
\text { PER C.MM.) }\end{array}$ & $\begin{array}{l}\text { HAEMOGLOBIN } \\
\text { (PER CENT.) }\end{array}$ & HAEMATOCRIT \\
\hline 15 & \multirow[t]{18}{*}{ ! } & $3 / 52$ & Pyloric stenosis & 6.62 & 128 & $66 \cdot 2$ \\
\hline 27 & & $8 / 12$ & Gastro-enteritis & $4 \cdot 44$ & 80 & $35 \cdot 9$ \\
\hline 28 & & $6 / 52$ & Gastro-enteritis & $4 \cdot 28$ & 96 & $42 \cdot 0$ \\
\hline 34 & & $3 / 12$ & Gastro-enteritis & $5 \cdot 30$ & 92 & $43 \cdot 2$ \\
\hline 42 & & $3 / 12$ & Gastro-enteritis & $4 \cdot 58$ & 82 & $35 \cdot 2$ \\
\hline 57 & & 852 & Pyloric stenosis & $5 \cdot 35$ & 98 & - \\
\hline 58 & & $5 / 12$ & Gastro-enteritis & $6 \cdot 33$ & 86 & $44 \cdot 4$ \\
\hline 59 & & $5 / 12$ & Gastro-enteritis & $6 \cdot 55$ & 94 & - \\
\hline 63 & & $5 / 52$ & Pyloric stenosis & 5.93 & 102 & $50-0$ \\
\hline 66 & & $8 / 12$ & Gastro-enteritis & $5 \cdot 36$ & 80 & $38 \cdot 2$ \\
\hline 67 & & $9 / 12$ & Gastro-enteritis & $7 \cdot 00$ & 88 & $43 \cdot 6$ \\
\hline 68 & & 212 & Gastro-enteritis & $4 \cdot 60$ & 86 & $39 \cdot 3$ \\
\hline 69 & & $9 / 12$ & Gastro-enteritis & $5 \cdot 74$ & 86 & $40 \cdot 1$ \\
\hline 70 & & $4 / 12$ & Gastro-enteritis & 5.00 & 82 & $40 \cdot 0$ \\
\hline 72 & & $2 / 12$ & Gastro-enteritis & $5 \cdot 43$ & 93 & $44 \cdot 9$ \\
\hline 73 & & $3 / 12$ & Gastro-enteritis & $5 \cdot 65$ & 104 & $45 \cdot 6$ \\
\hline 74 & & $7 / 52$ & Pyloric stenosis & $6 \cdot 24$ & 105 & $46 \cdot 6$ \\
\hline 75 & & $6 / 12$ & Gastro-enteritis & $6 \cdot 31$ & 90 & - \\
\hline 76 & 1 & $10 / 52$ & Gastro-enteritis & $4 \cdot 31$ & 78 & 一 \\
\hline 78 & & $7 / 12$ & Gastro-enteritis & $7 \cdot 17$ & 100 & - \\
\hline 83 & & $4 / 52$ & Pyloric stenosis & $5 \cdot 86$ & 114 & - \\
\hline 88 & & $5 / 52$ & Pyloric stenosis & $6 \cdot 33$ & 124 & - \\
\hline 89 & & $3 / 12$ & Pyloric stenosis & $5 \cdot 62$ & 98 & - \\
\hline 90 & & $6 / 52$ & Gastro-enteritis & $4 \cdot 57$ & 92 & - \\
\hline 94 & & $4 / 52$ & Pyloric stenosis & $7 \cdot 01$ & 128 & $58 \cdot 7$ \\
\hline 98 & & $6 / 12$ & Gastro-enteritis & $6 \cdot 49$ & 88 & $42 \cdot 7$ \\
\hline 100 & & $9 / 12$ & Gastro-enteritis & $7 \cdot 20$ & 100 & $52 \cdot 2$ \\
\hline 102 & & $6 / 52$ & Pyloric stenosis & 6.06 & 122 & $52 \cdot \overline{2}$ \\
\hline 103 & & $5 / 52$ & Pyloric stenosis & $5 \cdot 62$ & 103 & $45 \cdot 6$ \\
\hline 105 & & $5 / 12$ & Gastro-enteritis & $6 \cdot 40$ & 83 & $39 \cdot 4$ \\
\hline \multicolumn{4}{|c|}{ Average } & $5 \cdot 84$ & 97 & 44.9 \\
\hline
\end{tabular}

TABLE 2

THE CHANGES IN THE BLOOD IN DEHYDRATION

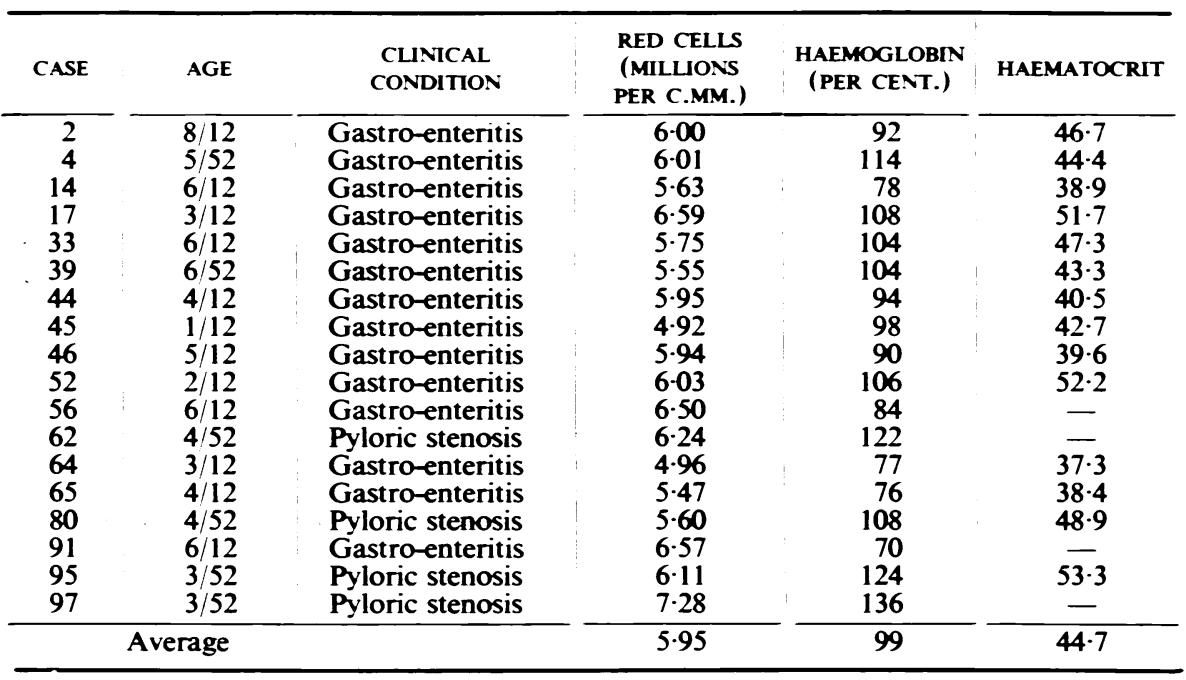

The above children had received fluid parenterally before their blood was examined 
TABLE 3

THE MOST EXTENSIVE CHANGES WHICH OCCURRED IN THE BLOOD IN DEHYDRATION

\begin{tabular}{|c|c|c|c|c|c|}
\hline CASE & AGE & $\begin{array}{l}\text { CUINICAL } \\
\text { CONDITION }\end{array}$ & $\begin{array}{l}\text { RED CELLS } \\
\text { (MILLONS } \\
\text { PER C.MM.) }\end{array}$ & $\begin{array}{l}\text { HAEMOGLOBIN } \\
\text { (PER CENT.) }\end{array}$ & HAEMATOCRIT \\
\hline $\begin{array}{r}2 \\
8 \\
9 \\
10 \\
16 \\
17 \\
20 \\
21 \\
27 \\
28 \\
33 \\
34 \\
35 \\
39 \\
44 \\
45 \\
46 \\
52 \\
56 \\
58 \\
59 \\
67 \\
68 \\
71 \\
77 \\
78 \\
90 \\
95 \\
97\end{array}$ & $\begin{array}{l}8 / 12 \\
3 / 12 \\
8 / 12 \\
3 / 12 \\
5 / 12 \\
3 / 12 \\
3 / 12 \\
9 / 52 \\
8 / 12 \\
6 / 52 \\
6 / 12 \\
3 / 12 \\
6 / 12 \\
6 / 52 \\
4 / 12 \\
6 / 52 \\
5 / 12 \\
2 / 12 \\
6 / 12 \\
5 / 12 \\
5 / 12 \\
9 / 12 \\
2 / 12 \\
4 / 12 \\
6 / 52 \\
7 / 12 \\
6 / 52 \\
3 / 52 \\
4 / 52\end{array}$ & $\begin{array}{l}\text { D. and V. Otitis } \\
\text { D. and V. } \\
\text { D. and V. Otitis } \\
\text { D. and V. } \\
\text { D. and V. Otitis } \\
\text { D. and V. } \\
\text { D. and V. } \\
\text { D. and V. Old P.S. } \\
\text { D. and V. } \\
\text { D. and V. } \\
\text { D. and V. Otitis } \\
\text { D. and V. } \\
\text { D. and V. Anaemia } \\
\text { D. and V. Old P.S. } \\
\text { D. and V. } \\
\text { D. and V. } \\
\text { D. and V. Otitis } \\
\text { D. and V. Old P.S. } \\
\text { D. and V. Otitis } \\
\text { D. and V. } \\
\text { D. and V. } \\
\text { D. and V. } \\
\text { D. and V. Otitis } \\
\text { D. and V. } \\
\text { D. and V. } \\
\text { D. and V. Otitis } \\
\text { D. and V. } \\
\text { Pyloric stenosis } \\
\text { D. and V. Old P.S. }\end{array}$ & $\begin{array}{l}6 \cdot 00 \\
5 \cdot 60 \\
5 \cdot 42 \\
5 \cdot 88 \\
8 \cdot 27 \\
7 \cdot 27 \\
5 \cdot 89 \\
5 \cdot 43 \\
6 \cdot 68 \\
5 \cdot 30 \\
5 \cdot 75 \\
5 \cdot 30 \\
7 \cdot 45 \\
5 \cdot 55 \\
6 \cdot 44 \\
5 \cdot 54 \\
7 \cdot 52 \\
6 \cdot 03 \\
6 \cdot 50 \\
6 \cdot 33 \\
6 \cdot 55 \\
7 \cdot 00 \\
5 \cdot 52 \\
6 \cdot 45 \\
5 \cdot 90 \\
8 \cdot 02 \\
5 \cdot 28 \\
6 \cdot 39 \\
7 \cdot 88\end{array}$ & $\begin{array}{r}92 \\
112 \\
104 \\
112 \\
126 \\
120 \\
105 \\
102 \\
107 \\
108 \\
104 \\
92 \\
98 \\
104 \\
100 \\
106 \\
106 \\
106 \\
84 \\
86 \\
94 \\
88 \\
104 \\
104 \\
111 \\
114 \\
106 \\
130 \\
154\end{array}$ & $\begin{array}{c}46 \cdot 7 \\
45 \cdot 5 \\
41 \cdot 1 \\
45 \cdot 5 \\
56 \cdot 7 \\
56 \cdot 7 \\
46 \cdot 5 \\
47 \cdot 8 \\
48 \cdot 9 \\
47 \cdot 3 \\
43 \cdot 2 \\
54 \cdot 0 \\
43 \cdot 3 \\
43 \cdot 8 \\
48 \cdot 9 \\
45 \cdot 5 \\
52 \cdot 2 \\
- \\
44 \cdot 4 \\
\overline{43 \cdot 6} \\
51 \cdot 8 \\
52 \cdot 8 \\
- \\
- \\
60 \cdot 0 \\
68 \cdot 5\end{array}$ \\
\hline \multicolumn{3}{|c|}{ Average } & $6 \cdot 32$ & 106 & $49 \cdot 3$ \\
\hline
\end{tabular}

It will be seen that the average red cell count, both in those infants who had received fluid parenterally and those who had not, is well over 5 millions per c.mm. In compiling these tables the age of each individual was not considered, but the red cell count normally alters so much during the first six months of life that it is essential to know the age of the patient and the normal red cell count for that age before any opinion concerning the concentration of the blood can be given. The graph depicted in fig. 1 was obtained by plotting red cell counts against age in a series of normal healthy Birmingham infants, and represents the unpublished results of investigations carried out by Dr. M. B. Cleland at the Children's Hospital, Birmingham. The dots superimposed on this graph represent the red cell counts of dehydrated infants of the same ages at the time of their admission to hospital and are seen to fall above the normal black line. It is, therefore, clear that whereas a red cell count of 5.5 millions per c.mm. is normal in an infant aged four weeks, a similar count in an infant of three months of age suggests a fair amount of dehydration.

Haemoglobin concentration is also increased by dehydration, as is obvious in fig. 2, which was constructed in the same way as the graph of red cells. Since 


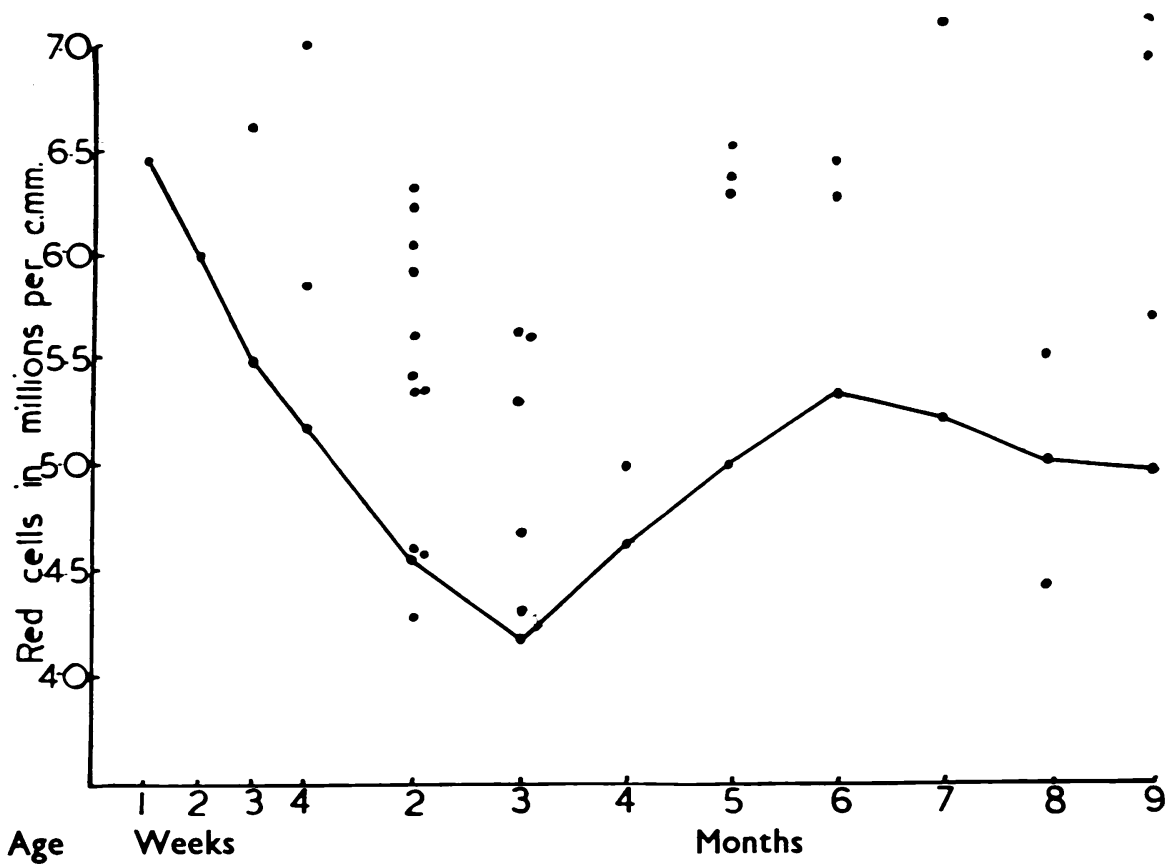

FIG. 1.-The continuous line represents the graph obtained by plotting red cell counts against age in normal infants. The dots represent dehydrated_infants plotted in the same way.

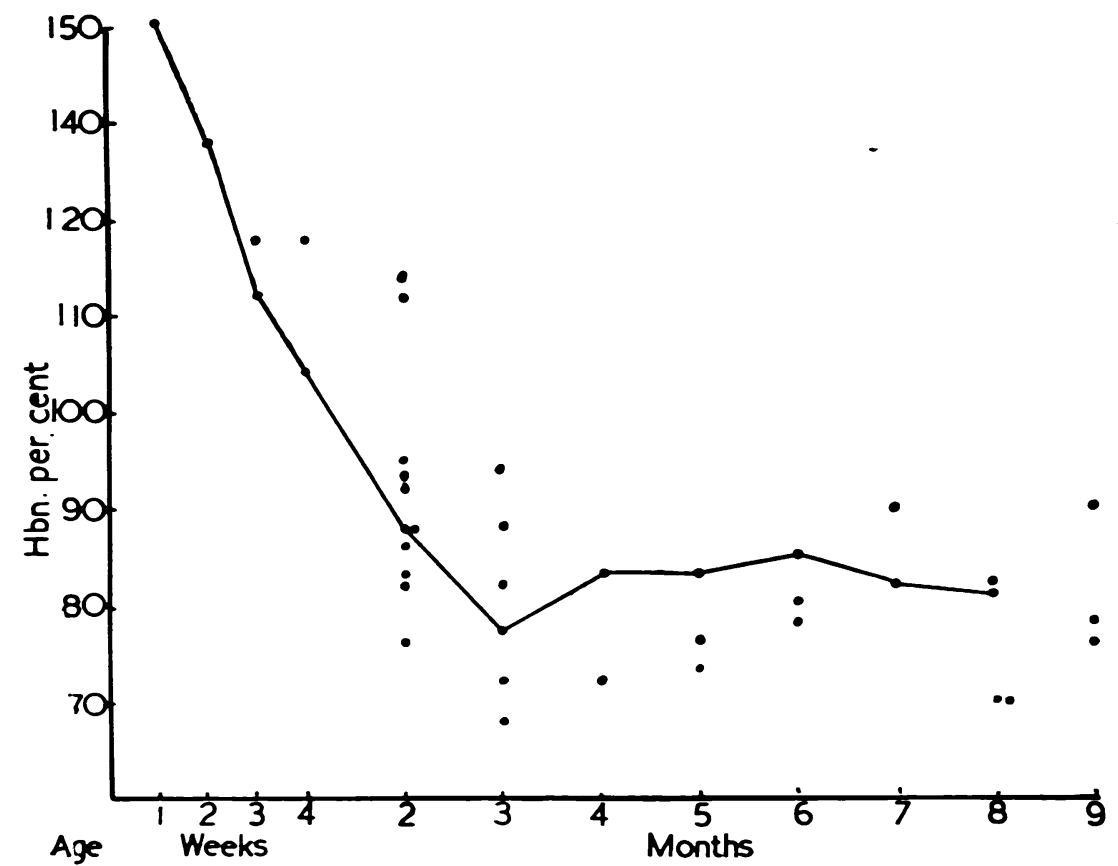

Fig. 2.-Haemoglobin plotted against age in normal (continuous line) and dehydrated (dots) infants. 
many of the patients were suffering from hypochromic anaemia, the concentration of haemoglobin does not appear so marked as that of the red cells ; hence, estimation of haemoglobin alone gave quite an inadequate indication of haemo-concentration.

The average haematocrit readings (tables 1 and 2) were 44.9 and 44.7 respectively. These values do not appear to be raised much above the usually accepted normal figure of 42.0 , but reference to fig. 3 (constructed in the same manner as fig. 1 and 2) shows that from the second to the eighth month normal readings are less than 38 . Concentration by dehydration is, therefore, considerable. The range of readings obtained lay between $35 \cdot 2$ and $66 \cdot 2$, the

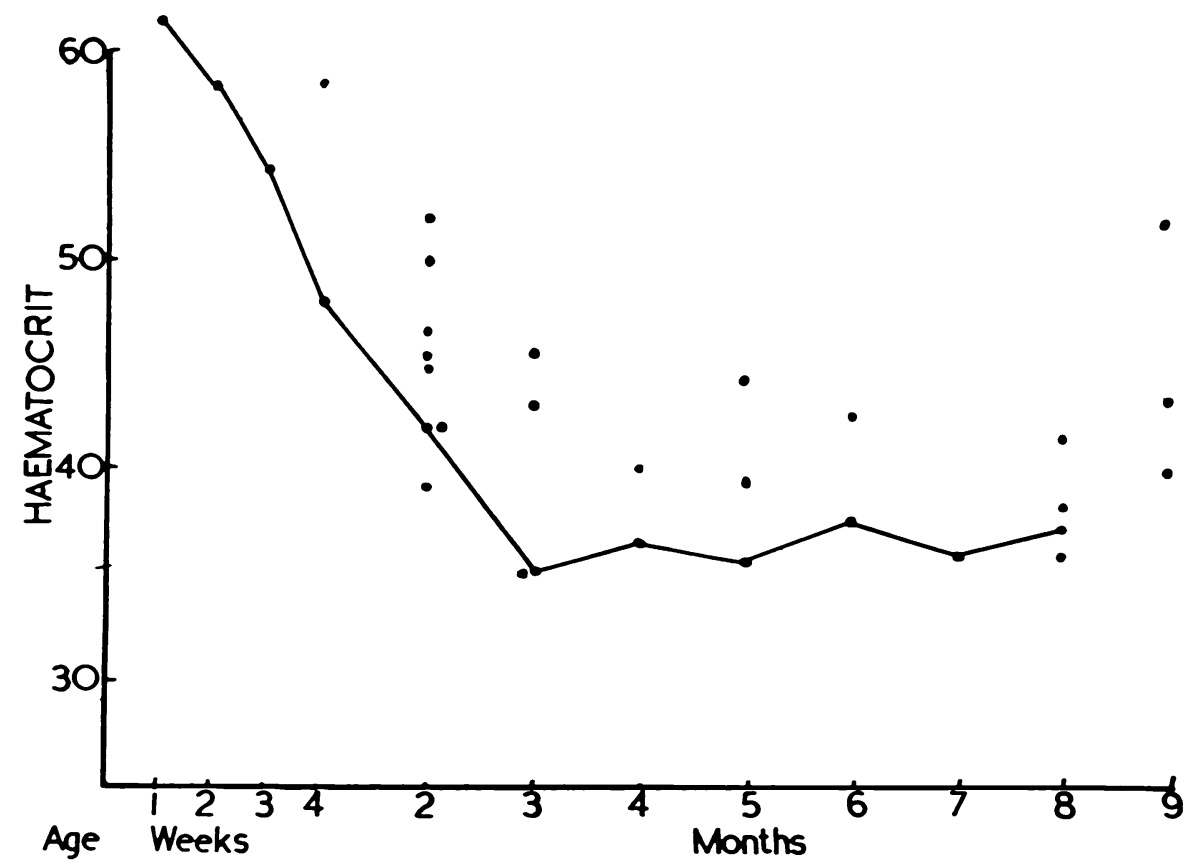

FIG. 3.-Haematocrit readings plotted against age in normal (continuous line) and dehydrated (dots) infants.

highest readings being found in dehydrated infants with pyloric stenosis. This finding is explained by the age of these patients : the oldest infant was twelve weeks old, the youngest three weeks, the average age of the fourteen cases being just over five weeks. At this age the normal red cell count is just under 5 millions per c.mm. and the colour index is still well over unity, so that the normal haematocrit reading is about $\mathbf{4 2 - 0}$. If a child of this age is dehydrated it is evident that the haematocrit reading will rise considerably above these normal figures. Actually, in the eight cases of pyloric stenosis examined, the average value was $52 \cdot 7$.

The lowest haematocrit readings occurred either in those children with gastro-enteritis who, whilst showing clinical evidence of dehydration, had little or no haemo-concentration, or in those who had well-marked hypochromic anaemia and resulting microcytosis. 
In assessing the degree of haemo-concentration it is important to take into consideration whether nutritional anaemia is present or not, and this for three reasons : First, it has been shown by Parsons, Hickmans and Finch (1937) that in an iron deficiency anaemia the number of red cells may actually be increased to 5.5 or even 6 millions per c.mm., as the result of the anaemia alone ; secondly, the colour index may be reduced to $0 \cdot 5$, so that the haemoglobin concentration will be only half that expected for the particular red cell count ; thirdly, as a result of the microcytosis, even when an increased number of red cells occurs, the haematocrit reading may be low and remain within normal limits even when there is dehydration.

\section{Chemical features}

The values of plasma chloride and plasma protein found in a series of thirtyfive infants with gastro-enteritis are set out in tables 4 and 5 . Those examined before the administration of parenteral fluid are grouped together in table 4, whilst table 5 comprises those who had been given parenteral fluid before the estimations were done: this division is necessary because the fluid administered contained sodium chloride, and also because the concentration of plasma protein was presumably reduced by the administration of fluid which did not contain protein.

TABLE 4

THE CHEMICAL CHANGES IN THE BLOOD IN DEHYDRATION

\begin{tabular}{|c|c|c|c|c|}
\hline CASE & AGE & CLINICAL CONDITION & $\begin{array}{l}\text { PLASMA } \\
\text { CHLORIDE } \\
\text { (MGM. NaCl } \\
\text { PER CENT.) }\end{array}$ & $\begin{array}{l}\text { PLASMA } \\
\text { PROTEN } \\
\text { (GRAMMES } \\
\text { PER CENT.) }\end{array}$ \\
\hline 27 & $8 / 12$ & $\left\{\begin{array}{l}\text { Mildly dehydrated. } \\
\text { Mildly dehydrated. } \\
\text { and L.) }\end{array}\right.$ & $\begin{array}{l}804 \\
687\end{array}$ & $\begin{array}{l}5 \cdot 43 \\
7 \cdot 11\end{array}$ \\
\hline $\begin{array}{l}28 \\
34 \\
42 \\
58 \\
59\end{array}$ & $\begin{array}{l}6 / 52 \\
3 / 12 \\
3 / 12 \\
5 / 12 \\
5 / 12\end{array}$ & $\begin{array}{l}\text { Malnourished and dehydrated. } \\
\text { Very ill and dehydrated. } \\
\text { Looks dehydrated. } \\
\text { Mildly dehydrated. } \\
\text { Dehydrated and toxic. Poor colour. } \\
\text { Cold. }\end{array}$ & $\begin{array}{l}687 \\
687 \\
730 \\
614 \\
629\end{array}$ & $\begin{array}{l}7 \cdot 17 \\
8 \cdot 62 \\
7 \cdot 06 \\
6 \cdot 61\end{array}$ \\
\hline $\begin{array}{l}66 \\
67 \\
68 \\
69 \\
70\end{array}$ & $\begin{array}{l}7 / 12 \\
9 / 12 \\
2 / 12 \\
9 / 12 \\
4 / 12\end{array}$ & $\begin{array}{l}\text { Rather dehydrated. Otherwise good. } \\
\text { Very dehydrated, and toxic. } \\
\text { Mildly dehydrated. Pale. } \\
\text { Mildly dehydrated. } \\
\text { Dehydrated and pale. Severe diar- } \\
\text { rhoea. }\end{array}$ & $\begin{array}{l}651 \\
679 \\
678 \\
603 \\
537\end{array}$ & $\begin{array}{l}5 \cdot 39 \\
5 \cdot 50 \\
4 \cdot 96 \\
6 \cdot 54 \\
6 \cdot 83\end{array}$ \\
\hline $\begin{array}{l}72 \\
73 \\
75\end{array}$ & $\begin{array}{l}2 / 12 \\
3 / 12 \\
6 / 12\end{array}$ & $\begin{array}{l}\text { Dehydrated. Poor tissue turgor. } \\
\text { Dehydrated. Very severe diarrhoea. } \\
\text { Dehydrated and toxic. Passing urine } \\
\text { well. }\end{array}$ & $\begin{array}{l}581 \\
647 \\
536\end{array}$ & $\begin{array}{l}7 \cdot 72 \\
5 \cdot 71 \\
8 \cdot 74\end{array}$ \\
\hline \multirow[t]{2}{*}{$\begin{array}{r}76 \\
78 \\
90 \\
98 \\
100 \\
105\end{array}$} & $\begin{array}{r}10 / 52 \\
7 / 12 \\
6 / 52 \\
6 / 12 \\
9 / 12 \\
5 / 12\end{array}$ & $\begin{array}{l}\text { Looks toxic. Not very dehydrated. } \\
\text { Extremely toxic and dehydrated. } \\
\text { Toxic. Poor turgor. Severe vomiting. } \\
\text { Dehydrated and toxic. } \\
\text { Dehydrated and toxic. Passing urine. } \\
\text { Very dehydrated and toxic-looking. }\end{array}$ & $\begin{array}{l}789 \\
672 \\
632 \\
545 \\
588 \\
691\end{array}$ & $\begin{array}{l}7 \cdot 62 \\
8 \cdot 17 \\
7 \cdot 44 \\
6 \cdot 58 \\
7 \cdot 86 \\
8 \cdot 28\end{array}$ \\
\hline & Average & & 651 & 6.98 \\
\hline
\end{tabular}


TABLE 5

THE CHEMICAL CHANGES IN THE BLOOD IN DEHYDRATION

\begin{tabular}{|c|c|c|c|c|}
\hline CASE & AGE & CUNICAL CONDITION & $\begin{array}{l}\text { PLASMA } \\
\text { CHLORIDE } \\
\text { (MGM. NaCl } \\
\text { PER CENT.) }\end{array}$ & $\begin{array}{l}\text { PLASMA } \\
\text { PROTEIN } \\
\text { (GRAMMES } \\
\text { PER CENT.) }\end{array}$ \\
\hline 2 & $8 / 12$ & $\begin{array}{l}\text { Dehydrated. Otitis. Vomiting } \\
\text { marked. }\end{array}$ & 674 & $7 \cdot 70$ \\
\hline $\begin{array}{r}4 \\
14 \\
17 \\
33\end{array}$ & $\begin{array}{l}5 / 52 \\
6 / 12 \\
3 / 12 \\
6 / 12\end{array}$ & $\begin{array}{l}\text { Marked dehydration. Old pyloric. } \\
\text { Dehydrated and pale. Poor turgor. } \\
\text { V. dehydrated and ill. Previous B.T. } \\
\text { Dehydrated and ill. Pneumonia. } \\
\text { Otitis. }\end{array}$ & $\begin{array}{l}750 \\
628 \\
727 \\
716\end{array}$ & $\begin{array}{l}- \\
8 \cdot 33 \\
7 \cdot 76\end{array}$ \\
\hline $\begin{array}{l}39 \\
44\end{array}$ & $\begin{array}{l}6 / 52 \\
4 / 12\end{array}$ & $\begin{array}{l}\text { Dehydrated and toxic. Old pyloric. } \\
\text { Looks v. dehydrated and toxic. } \\
\text { Otitis. }\end{array}$ & $\begin{array}{l}746 \\
818\end{array}$ & $\begin{array}{l}6 \cdot 51 \\
7 \cdot 23\end{array}$ \\
\hline $\begin{array}{l}45 \\
46 \\
52 \\
56\end{array}$ & $\begin{array}{l}1 / 12 \\
5 / 12 \\
2 / 12 \\
6 / 12\end{array}$ & $\begin{array}{l}\text { Dehydrated. Poor turgor. } \\
\text { Mildly dehydrated. Otitis. } \\
\text { Dehydrated. Old pyloric stenosis. } \\
\text { Dehydrated and toxic. Severe } \\
\text { diarrhoea. }\end{array}$ & $\begin{array}{l}736 \\
738 \\
753 \\
820\end{array}$ & $\begin{array}{l}5 \cdot 27 \\
5 \cdot 17 \\
6 \cdot 38 \\
6 \cdot 98\end{array}$ \\
\hline \multirow[t]{2}{*}{$\begin{array}{l}64 \\
65 \\
91\end{array}$} & $\begin{array}{l}3 / 12 \\
4 / 12 \\
6 / 12\end{array}$ & $\begin{array}{l}\text { Mildly dehydrated. } \\
\text { Very dehydrated. Pale. } \\
\text { Rather dehydrated. Pale. }\end{array}$ & $\begin{array}{l}740 \\
696 \\
651\end{array}$ & $\begin{array}{l}5 \cdot 34 \\
4 \cdot 67 \\
5 \cdot 75\end{array}$ \\
\hline & Average & & 728 & $6 \cdot 42$ \\
\hline
\end{tabular}

All the cases in this table had received fluid parenterally before examination of the blood was carried out.

Plasma chloride. The amount of chloride in the plasmas of the twenty-one infants recorded in table 4 ranges from $804 \mathrm{mgm}$. to $536 \mathrm{mgm}$., the average being $651 \mathrm{mgm}$. per cent. These figures are considerably higher than those obtained from the series of normal infants, in which the average was $607 \mathrm{mgm}$. and the range 560 to $640 \mathrm{mgm}$. per cent. Consideration of the individual values shows that in eleven cases they were above 640 and in three below 560, whilst the remainder were within the normal limits. The height of the plasma chloride did not of necessity vary with the degree of dehydration nor with the clinical condition of the patient. For example, the highest reading of $804 \mathrm{mgm}$. per cent. was associated with only mild dehydration, whereas several children who were more dehydrated and worse clinically had under $600 \mathrm{mgm}$. per cent. of chloride in the plasma.

COMMENT. The observations of other workers on the chloride content of the plasma in dehydration also show that it may be high, normal or low. Some (Hartmann, 1928 ; Hoag and Marples, 1931 ; and Pincus and Kiser, 1931) found a large number of high values similar to those discussed above, whereas others (Darrow and Buckman, 1928 ; Hamilton et al., 1929 ; McIntosh et al., 1930 ; and Cooper, 1937) have reported a larger proportion of normal and low values. Boyd (1926) reports a series of sixty-six cases of acute intestinal intoxication of which thirty-three had normal chloride values, twenty-one were below normal and twelve above normal. In seven of her cases in which there was sudden, overwhelming toxaemia the average plasma chloride was $677 \mathrm{mgm}$. 
per cent., whereas in cases of insidious onset the average was $590 \mathrm{mgm}$. per cent. She concludes that there is no definite relationship between the level of chloride in the plasma and the degree of toxaemia, and that the height of the plasma chloride is of no value in prognosis, which is not surprising when the number of factors affecting the chloride content is remembered. These factors may be considered under three headings :

LOSS OF ELECTROLYTES. When there is much loss of hydrochloric acid vomiting alone leads to alkalosis, a condition which is found especially associated with pyloric stenosis. On the other hand, diarrhoea alone tends to cause acidosis, since the intestinal juices are not reabsorbed and sodium and potassium are lost in the stools. A large amount of sodium chloride also may be lost in the stools in diarrhoea, although in health only small amounts are excreted by the bowel. The combination of vomiting and diarrhoea in gastroenteritis may, therefore, lead to alkalosis or acidosis, either of which conditions may be compensated or uncompensated. In point of fact the greater loss usually occurs in the stools, so that vomiting does not materially affect the acidosis resulting from diarrhoea ; moreover, sick infants, especially those suffering from infections or nutritional disturbances, have a distinctly lower gastric acidity than normal infants, so that the amount of hydrochloric acid lost in the vomit is small (Marriott, 1923). In gastro-enteritis, therefore, the plasma bicarbonate is relatively lowered, because there is a loss of base, especially sodium, from the gut ; bicarbonate may be excreted with it or there may be a compensatory loss of $\mathrm{CO}_{2}$ from the lungs. The amount of chloride as sodium chloride in the plasma is usually much less affected.

WATER DEFICIT. Dehydration affects all the tissues of the body. It has been estimated that when an adult shows signs of dehydration he has already lost fluid representing 6 per cent. of his body weight (Coller and Maddock, 1935). Although there is an attempt to maintain the blood volume at the expense of the tissues, there is, nevertheless, a loss of fluid from the circulation. This has been conclusively proved by many observers and is supported by my own figures. Marriott and Hartmann (1933) have drawn attention to the important point that the concentration of chloride and fixed base in the plasma may be normal or above normal in gastro-enteritis because, although these substances are lost from the body in considerable amounts, there is at the same time an even greater loss of water. The effect of this water loss may be enhanced by a diminished intake associated with vomiting and anorexia.

RENAL INSUFFICIENCY. Dehydration causes oliguria or even anuria. This affects the output of excretory products and electrolytes as well as water, so that the kidney is prevented from getting rid of excess acid radicles, of which the most important is the chloride. The significance of this renal insufficiency is stressed by Hamilton et al. (1929), Hartmann (1929), Marriott (1934), and Marples et al. (1934).

In summary, then, the relatively small loss of chloride as opposed to base, the concentration of the circulating blood and the renal deficiency are all factors in producing an apparent, if not actual, increased amount of chloride in the plasma in the gastro-enteritis of infancy. The plasma chloride, however, may 
be high, normal or low according to the amount lost in the stools and vomit in relation to the water deficit.

Plasma protein. In considering changes in the plasma of dehydrated infants it is most important to remember that the normal values are less in the infant than in the adult. During the first eighteen months of life there is a gradual increase in the concentration of serum proteins until adult figures are reached (Peters and van Slyke, 1931). Normal figures for plasma protein are given as :

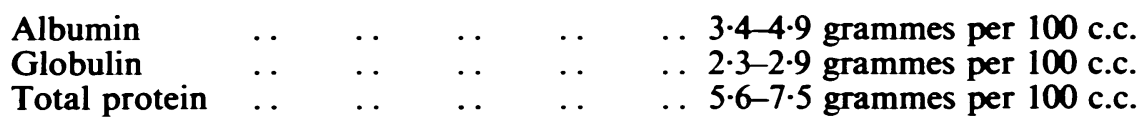

With such widely differing values it is obviously difficult to gain much, if any, information concerning hydration of the blood from an isolated determination of plasma protein. To obtain a standard 156 estimations were carried out on the series of normal infants mentioned above, and an average figure of 6.31 grammes of protein per 100 c.c. of plasma was obtained. The highest value was 7.91 grammes per cent. and the lowest 4.77 .

The values obtained in the series of dehydrated infants are set out in tables 4 and 5 , those recorded in table 5 having received some sort of fluid parenterally before the blood was examined, which probably accounts for the lower values found in these children. The results are summarized in table 6 , from which it will be seen that on an average the plasma protein in the dehydrated cases was a little higher than in a comparable group of normal infants.

TABLE 6

SUMMARY OF PLASMA PROTEIN VALUES IN NORMAL AND DEHYDRATED INFANTS

\begin{tabular}{|c|c|c|c|c|c|c|c|}
\hline & & & & 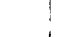 & \multirow{2}{*}{ NORMAL } & \multicolumn{2}{|c|}{ DEHYDRATION } \\
\hline & & & & & & NO FLUID & AFTER FLUID \\
\hline Average & . & . & . & .. & $6 \cdot 31$ & 6.98 & $6 \cdot 48$ \\
\hline Maximum & . & . & . & . & $7 \cdot 91$ & $8 \cdot 74$ & $8 \cdot 33$ \\
\hline Minimum & .. & . & . & . & $4 \cdot 77$ & 4.96 & $4 \cdot 67$ \\
\hline
\end{tabular}

Comment. The majority of observers agree that the plasma protein values are increased in dehydration, Marriott (1934) stressing the point that the plasma protein becomes concentrated as a result of a sudden acute loss of water and that when this anhydraemia has persisted for a few days decrease in the concentration occurs due to an actual destruction of protein ; nevertheless, some investigators have used the degree of plasma protein concentration to indicate the state of hydration of the circulating blood. In the present series of cases there was no definite relationship between the concentration of plasma protein and the red cell, haemoglobin and haematocrit readings, except that all these 
values tended to be raised in dehydration. Many workers agree with these findings and hold that the estimation of plasma protein is an unreliable method of assessing the degree of hydration of the blood (Darrow and Buckman, 1928 ; McIntosh et al., 1930 ; and Marriott, 1934).

\section{CHEMICAL FEATURES OF PYLORIC STENOSIS}

Plasma chloride. The dehydration which occurs in uncomplicated cases of congenital hypertrophic pyloric stenosis is the result of fluid loss from vomiting because, owing to constipation, less fluid than normal is lost in the stools. A considerable amount of hydrochloric acid and sodium chloride is lost in the vomit, so that the plasma chloride falls, a fact demonstrated by Gamble and Ross (1924) in experimental pyloric stenosis in dogs, in one of whose experiments the following figures were obtained:

Before operation .. $\quad . . \quad \quad \ldots \quad \quad \ldots \quad \quad \ldots \quad \quad \ldots 613$ mgm. per 100 c.c.

18 hours after operation .. $\quad . .6 \quad \ldots . \quad \ldots \quad \ldots 540$ mgm. per 100 c.c.

29 hours after operation .. $\quad . \quad \ldots \quad \ldots \quad \ldots \quad \ldots 473$ mgm. per 100 c.c.

42 hours after operation .. $\quad \ldots \quad \ldots \quad \ldots \quad \ldots \quad \ldots 393 \mathrm{mgm}$. per 100 c.c.

According to Morris and Graham (1929), a low blood chloride is one of the most constant chemical findings in infantile pyloric stenosis, and at one time they held the view that the reduction of chloride bore some relation to the severity of the vomiting : but in a later paper (1931) they stated that there might be a fall in the blood chloride during a prolonged absence of vomiting.

The plasma chloride values of a few cases of pyloric stenosis are shown in table 7. Five of these fourteen infants had received normal saline sub-

TABLE 7

THE BLOOD CHEMISTRY IN PYLORIC STENOSIS

\begin{tabular}{|c|c|c|c|c|}
\hline CASE & AGE & CUNICAL CONDITION & $\begin{array}{c}\text { PLASMA } \\
\text { CHLORIDE } \\
\text { (MGM. NaCl } \\
\text { PER CENT.) }\end{array}$ & $\begin{array}{l}\text { PLASMA } \\
\text { PROTEIN } \\
\text { (GRAMMES } \\
\text { PER CENT.) }\end{array}$ \\
\hline 57 & $8 / 52$ & $\begin{array}{l}\text { Dehydrated. Limbs cold and } \\
\text { cyanosed. }\end{array}$ & 521 & $6 \cdot 51$ \\
\hline 62 & $4 / 52$ & $\begin{array}{l}\text { Dehydrated. Poor turgor. Previous } \\
\text { s.c. saline. }\end{array}$ & 563 & $6 \cdot 28$ \\
\hline $\begin{array}{r}63 \\
74 \\
80 \\
81 \\
83 \\
87 \\
88 \\
89 \\
94 \\
95 \\
96 \\
97 \\
102 \\
103\end{array}$ & $\begin{array}{r}5 / 52 \\
7 / 52 \\
3 \frac{1}{2} / 52 \\
5 / 52 \\
4 / 52 \\
3 / 12 \\
5 / 52 \\
12 / 52 \\
4 / 52 \\
3 / 52 \\
7 / 52 \\
3 / 52 \\
6 / 52 \\
5 / 52\end{array}$ & $\begin{array}{l}\text { Condition very fair. } \\
\text { Condition quite good. } \\
\text { Fair. Previous s.c. saline. } \\
\text { Fair. Previous s.c. saline. } \\
\text { Mild dehydration. Condition fair. } \\
\text { Dehydration mild. Condition poor. } \\
\text { Condition fair. } \\
\text { Dehydrated. Poor turgor. } \\
\text { Very dehydrated. Condition poor. } \\
\text { Fair. Previous s.c. saline. } \\
\text { Condition good. } \\
\text { Very dehydrated. } \\
\text { Condition fair. Mild dehydration. } \\
\text { Condition fair. }\end{array}$ & $\begin{array}{l}570 \\
566 \\
526 \\
569 \\
520 \\
547 \\
456 \\
555 \\
426 \\
529 \\
427 \\
573 \\
552 \\
459\end{array}$ & $\begin{array}{l}5 \cdot 58 \\
5 \cdot 63 \\
6 \cdot 29 \\
6 \cdot 58 \\
7 \cdot 39 \\
5 \cdot 63 \\
7 \cdot 18 \\
5 \cdot 51 \\
8 \cdot 74 \\
6 \cdot 38 \\
5 \cdot 61 \\
6 \cdot 71 \\
7 \cdot 02 \\
6 \cdot 61\end{array}$ \\
\hline & Average & & 522 & $6 \cdot 48$ \\
\hline
\end{tabular}


cutaneously (100 c.c. as a rule), but the remaining nine had had no fluid administered parenterally. Only five of these patients had values in excess of the accepted minimal normal figure of $560 \mathrm{mgm}$. per cent., and of these three had been given normal saline subcutaneously before the blood was examined. Thus, these figures, if not actually below normal were all on the low side of normal. Nowadays figures as low as those in Morris and Graham's series are not found because the diagnosis of pyloric stenosis is made earlier than formerly, usually within two or three days of the first attack of vomiting.

Plasma protein. The plasma protein values with an average reading of 6.48 grammes and a range of 8.74 grammes are slightly above normal, undoubtedly the result of dehydration.

\section{CONCLUSIONS AND SUMMARY}

The blood changes in a series of fifty-one infants showing varying degrees of dehydration (thirty-five suffering from gastro-enteritis and sixteen from pyloric stenosis) have been studied.

The red blood cell count was raised, the average count being well over 5 millions per c.mm., and it has been shown that this represents a considerable increase in the red count in infants of this age, although some of the increase may be due to nutritional anaemia. The haemoglobin was also increased, but often to a less degree than the red cell count because of the presence of hypochromic anaemia. Estimation of haemoglobin alone was not an adequate indication of haemoconcentration. When allowance was made for age and any nutritional anaemia that may have been present, the haematocrit reading was considerably above normal.

The plasma chloride in gastro-enteritis was variable, the average for the series was raised (651 mgm. per cent.), but in some cases the values were below normal. The height of the plasma chloride did not necessarily vary with the degree of dehydration or clinical condition. It was shown that an apparent, if not actual, rise in concentration of plasma chloride in gastro-enteritis and dehydration is due to:- (a) The relatively small amount of chloride as compared with base lost; (b) the concentration of the circulating blood; and (c) renal insufficiency. In pyloric stenosis the plasma chloride was either diminished slightly or on the low side of normal.

Plasma protein in gastro-enteritis was on the average a little higher than in a series of normal infants. The plasma protein concentration cannot be used as an indication of the state of hydration of the circulating blood. Plasma protein in pyloric stenosis was slightly above normal. In this series of cases no definite relation was found between concentration of plasma protein and blood cell, haemoglobin and haematocrit reading, except that all values tend to be raised above normal in dehydration. 


\section{REFERENCES}

Boyd, G. (1926). Amer. J. Dis. Child., 31, 514.

Coller, F. A., and Maddock, W. G. (1935). Ann. Surg., 102, 947.

Cooper, E. D. (1937). Arch. Dis. Childh., 12, 347.

Darrow, D. C., and Buckman, T. E. (1928). Amer. J. Dis. Child., 36, 248.

Eisenman, A. J. (1929). J. biol. Chem., 82, 411.

Gamble, J. L., and Ross, S. G. (1924). J. clin. Invest., 1, 403.

Hamilton, B., Kajdi, L., and Meeker, D. (1929). Amer. J. Dis. Child., 38, 314.

Hartmann, A. F. (1928). Ibid., 35, 557.

(1929). Colo. Med., 26, 373.

Hoag, L. A., and Marples, E. (1931). Amer. J. Dis. Child., 42, 291.

McIntosh, R., Kajdi, L., and Meeker, D. (1930). J. clin. Invest., 9, 333.

Marples, E., Cohen, H., and Talamo, H. (1934). Amer. J. Dis. Child., 47, 331.

Marriott, W. M. (1923). Ibid., 26, 542.

- (1934). Sth. med. J., 27, 131.

- and Hartmann, A. F. (1933). J. Pediat., 3, 187.

Morris, N., and Graham, S. (1929). Arch. Dis. Childh., 4, 336.

- , and - (1931). Ibid., 6, 27.

Parsons, L. G., Hickmans, E. M., and Finch, E. (1937). Ibid., 12, 369.

Peters, J. P., and van Slyke, D. D. (1931). Quantitive Clinical Chemistry, London.

Pincus, J. B., and Kiser, W. H., Jr. (1931). Quoted by Hoag and Marples.

van Slyke, D. D. (1923). J. biol. Chem., 58, 523. 